\title{
16. Housing and neighbourhood: basic needs, governance and social innovation
}

\author{
Peter Brokking, Marisol García, Dina Vaiou \\ and Serena Vicari Haddock
}

\section{INTRODUCTION}

The financial crisis that began in 2008 has profoundly reorganised existing welfare state trajectories, affecting social services provision all over Europe (Martinelli, Chapter 1, in this volume). Earlier retrenchment of the State from public provision of social services and investment in public infrastructures had already modified these trajectories, also in countries not (or less) affected by the crisis. In this context, the provision of, and access to, housing is not an exception. This chapter focuses on initiatives and practices to meet needs in the area of housing and neighbourhood services that emerged from the restructuring of welfare systems and the recent, ongoing financial crisis.

There is widespread agreement among contemporary scholars that housing and neighbourhoods are under particular stress as the logic of the market becomes increasingly pervasive and that the area of need has grown, affecting different social groups who are bearing the brunt of the crisis. Following Cassiers and Kesteloot (2012), there are four processes that have brought about the expansion of unmet social needs. First, there is globalisation, which directed investment toward the economic competitiveness of cities and territories in preference to the welfare of their citizens. Secondly, there is financialisation, the process of global expansion of credit, which has brought about increasing investment in real estate and an unprecedented rise in housing prices. These two processes have driven the transformation of low-cost housing areas into primary real estate developments and have induced the growth of speculative housing markets. The third process is flexibilisation of the labour market, which has led to unstable and unprotected work arrangements, temporary employment, involuntary part-time work and low-paid employment and thus to an 
increase in numbers of the working poor as well as high levels of unemployment. Finally, there is restructuring of the State and the privatisation of public services, which has engendered further dynamics of exclusion and deprivation. To these four processes, we add two demographic factors (see Martinelli, Chapter 1). First, migration involving increasing numbers of migrants seeking safety and new opportunities, who, faced with discrimination and potential exclusion, give rise to a differentiated demand for social assistance and housing. The second demographic factor is the ageing population, which results in large groups of older people who, with reduced pensions and assets in the form of housing property, are potentially less able to buy health and assistance services in the market.

The four processes and the demographic factors manifest the intimate relationship between housing and welfare services, which becomes even more evident when housing is interpreted to be more than a shelter. Housing in a broader perspective is associated with access to basic services such as potable water, sanitation, healthcare and education, as well as protection against forced evictions and natural threats to health and life (Rolnik, 2014). This understanding of housing as a gateway to other rights is based on Lefebvre's notion of the city as oeuvre, which refers to the right to belong to and the right to co-produce urban spaces (Lefebvre, 1968). Although Lefebvre's ideas are in contrast with the neoliberal developments of recent decades, his understanding of the inclusive city and citizenship are still pertinent for today's policy-making. Moreover, the perception that housing and neighbourhoods are interlinked entities in the welfare state remains topical, as local amenities of neighbourhoods, for example schools and health services, contribute to the capitalised value of homes in the housing market (Cheshire and Sheppard, 2004).

The reforms of welfare and housing systems in the last two decades have changed the relation between housing and the welfare state. The recent financial and economic crisis accentuated housing privatisation and marketisation in different European countries. The impacts are evident in a large number of major European cities, which have experienced severe housing crises, with the result that housing access and affordability have become increasingly difficult for large groups of people. The pending resettlement of large numbers of refugees in the EU is adding new pressure to rethink the housing question as part of the welfare of citizens. The housing emergency includes not only highly visible phenomena like the increase in homelessness and in the squatting component of urban movements, but also manifests itself in other developments such as the rise in the number of house evictions or the re-entry of young people into their parents' home. Moreover, the crisis is affecting sections of society previously not regarded as 'vulnerable'. This includes mainly, but not only, the young and the 
sectors of the middle classes affected by unemployment and underemployment. Under the pressure of fiscal austerity, the reduction and privatisation of public services such as social assistance, education and community amenities, cities are proving unable to respond to social needs. To counter these deficiencies, a wide range of bottom-up initiatives has emerged to cope with urgent housing needs and the lack of public support to people in need at different geographical scales, including the local/neighbourhood level. These socially innovative practices fill, to some extent, the gaps in neighbourhoods of cities where the welfare state no longer provides services related to, for example, housing, education and health care or where households can no longer afford to buy these services from private service providers.

The present chapter offers an analysis of these developments. First, we examine the role of housing provision and production as a key redistributive domain of traditional welfare states, highlighting the trends towards marketisation and stressing the importance of initiatives to cope with what has been denounced globally as a 'housing emergency'. Here we also examine the rise of the neighbourhood as a relevant scale of analysis in the current circumstances. Second, we discuss social innovation as an umbrella theoretical reference under which a wealth of responses to the retrenchment of the State and the resulting reduction in the provision of public services and urban amenities has been produced. Here we make use of cases taken from the COST Action IS1102 SO.S. COHESION - Social services, welfare states and places, as illustrations of our argument, rather than as 'background material' upon which to make conceptual claims. The cases address socially innovative responses from civil society or grassroots movements to particular unmet needs and exclusionary dynamics in housing and neighbourhood services in cities. ${ }^{1}$ Third, in the concluding section, we summarise our main points and propose a new take on them, underlining the challenges that socially innovative practices in the areas of housing and neighbourhood present for governance at various levels of policy-making.

\section{COPING WITH UNMET NEEDS AT TIMES OF CRISIS: HOUSING AND NEIGHBOURHOOD}

The financial and economic crisis of 2008 follows a long process of restructuring and withdrawal of the State from public provision of social services, social housing and investment in public infrastructures. The shrinking of social housing and/or publicly protected housing has led to increasingly unmet housing needs, to ever larger numbers of families on waiting lists and often to more socially excluded people and deprived and dilapidated 
neighbourhoods (CECODHAS, 2012). In these dire conditions, further aggravated by austerity policies, many initiatives have sprung up in different places to cope with unmet needs and to contribute to the development of social inclusion mechanisms (Maloutas and Malouta, 2004; Witten et al., 2003). Such initiatives have functioned as 'seedbeds of experimentation and social innovation' (Rodriguez, 2009, p. 86), putting forward an extraordinary variety of socially innovative practices to meet housing needs and enhancing patterns of inclusion and belonging in which the neighbourhood has acquired a renewed importance. This section will address both issues, the growth of precarious housing conditions and the emergence of local solidarity initiatives, in turn.

\section{Understanding the Housing Question Today}

The right to housing, recognised in international documents, for example the UN Declaration of human rights and the European social charter, has meant for several decades that housing was considered an area for welfare policy (Bengtsson, 2001). This justified the need for state intervention in welfare societies to secure the provision of housing to households with lesser means, for example through systems for social housing. However, since the 1990s an increasing share of households acquire their housing on the market, with only limited government intervention. At the same time, the number of people who have access to social housing is decreasing due to the reduction of public investment in public housing programmes in all European countries except France, Austria and Denmark (García and Vicari Haddock, 2016). As a result of the dominance of home ownership and the residualisation of social housing, housing holds an ambiguous and shifting position in the margins of the welfare state (Harloe, 1995).

Transformations in housing systems have been part of a larger restructuring of welfare relations, based on ideas such as individual responsibility and choice which are also embedded in the housing policy discourse (Malpass, 2008). The changes in housing systems have been supported by a process of deregulation and liberalisation, which began in the early 1980s and accelerated in the 1990s. Initially, the measures focused on deregulation of the rental sector designed to stimulate investments (Clapham, 2006), and on changes in housing subsidy systems (Holmqvist and Magnusson Turner, 2014). A further withdrawal of the state took place in the 1990s by privileging owner occupation, for example through 'right to buy' programmes (Doherty, 2004) and the liberalisation of the mortgage market to enhance financial assets for financing home ownership (Rolnik, 2013).

These market-oriented regulatory reforms have contributed to the commodification of urban housing provision (Kadi and Ronald, 2014), in which 
the logic of the market has become increasingly pervasive. Hence, housing is increasingly considered as a commodity for individual consumption (as first and second residences) but also as capital investment in a context of more or less constant housing price increases. Ultimately, home ownership has become a source to meet income needs in old age, where the owners consume the value of the property through equity release (Doling and Elsinga, 2012). In terms of housing need satisfaction, housing has turned into a conditional right constrained by financial commitments and risks, which has affected the prospects and conditions of urban households. The implications of this transformation vary, as they depend on local economic, political and cultural circumstances and require a detailed understanding of prevailing housing situations. As for home ownership, a significant expansion can be noted among all income groups in almost all EU-15 countries during the last three decades (Norris and Winston, 2012), but aggregate home ownership figures conceal differences among countries. For example, in Southern European countries high home ownership rates are widespread even among lower income groups as a result of strong family support either in cash or in-kind (land or labour). Yet, low-income households have burdensome housing costs and poor housing standards (Norris and Winston, 2012), which means that a certain amount of housing needs remain unmet even within the high percentage of home ownership.

The commodification of urban housing markets is central to an understanding of the marginalisation or exclusion of lower-income groups (Kadi and Ronald, 2014) and the diluted right to decent accommodation and living environments. Urban transformations and, in particular, policies of urban regeneration during the 1990s and 2000s to upgrade deprived neighbourhoods, triggered dynamics of displacement of low-income people, exclusion from newly developed places and the loss of a sense of belonging and identity. This displacement is not the result of individual household preferences, but rather of institutional factors behind these preferences, such as the state of the housing market and public policy (Slater, 2009), which reflect the neo-liberal state transformations towards commodification of urban housing markets.

The commodification of housing in combination with the liberalisation of the mortgage market fuelled housing markets worldwide, which resulted in an upswing of house prices. Increasing prices with diminishing state subsidies place an 'unreasonable burden' on household income (Edgar et al., 2002). In many countries house prices rose rapidly in the early 2000s, but after the financial crisis house prices declined dramatically in many (for example Spain, Denmark, Ireland and the Netherlands), but not all, European countries (Whitehead et al., 2014). This has affected a large number of families, even those that were not in vulnerable circumstances 
before the crisis. Since then housing affordability has become a major problem in many European cities, especially for young people but also for the unemployed, for some migrants and for the poor. The financial crisis has brought about an increase in arrears on mortgage payments, in mortgage defaults, in the numbers of housing repossessions and in evictions for failing to pay mortgages and monthly rent. To protect households from arrears and foreclosures, governments have adopted stricter mortgage regulations, which ultimately mean that particular groups and areas are excluded from the market for housing mortgage (Zwiers et al., 2016). Housing affordability problems following the financial crisis have resulted in the exclusion of large numbers of households. These exclusionary processes have stronger effects in societies where other features of the welfare state are missing or had historically been minimal. In these societies 'the symbolic and socioeconomic status of the home and its role in an implicit welfare economy has been enhanced' (Ronald, 2012, p.3). In Southern European countries, for example, housing ownership is a fundamental capital good as well as a family source for inter-generational solidarity. It has been essential to family welfare because of the low level of protection provided by the welfare state, but it gradually becomes a burden when households depend on mortgages they cannot pay back.

The overall vulnerability of individual households has increased as a consequence of the regulatory reforms of the last three decades and the resulting increased reliance on the market, which, in combination with the decrease in the provision of social housing, in effect means that the right to housing is no longer guaranteed in contemporary welfare states. It is a vulnerability which affects not only lower-income groups but also middleincome households who suffer from the consequences of the housing market collapse and the economic recession. Besides losing their homes, these groups risk being excluded from access to basic services, partly as a result of austerity measures that aim to reduce public spending. In response to these developments many movements and (local) initiatives have arisen to cope with increasingly unmet housing needs, thus linking the patterns of access to housing to broader processes of urban restructuring at different scales, including the neighbourhood. One could thus argue that the global crisis of 2008 has contributed to reviving the relevance of the neighbourhood as a spatial scale at which demands left unanswered are expected to find satisfaction.

\section{Re-discovering the Neighbourhood}

It can be said that the local level, and the neighbourhood as part of it, have recently been 're-discovered' as an analytical and policy scale in many 
cities. This chapter follows one strand of analysis, which has associated the neighbourhood with innovative approaches to urban restructuring and regeneration and as a privileged locus for social innovation. As Moulaert (2009) explains, at the neighbourhood scale problems of decline and restructuring are more immediately experienced and agents responsible for them more readily identifiable, while it is at this level too that alternatives are constituted, often in the cracks of the system, and become known/ shared. Urban neighbourhoods thus emerge as a focus of research on often innovative coping and/or resisting practices and as a place of experimentation with new forms of governance. In many Southern European cities, in particular, solidarity initiatives have sprung up, especially after the 2011 'indignados' movements, with diverse targets, varying actors and outcomes, as an arena for claims to the city and as a set of resources upon which (local) initiatives rely (Vaiou and Kalandides, 2016).

In the post-1989 literature, many urban scholars emphasise the importance of ever broader scales of reference, mobility, speed and time-space compression associated with processes of globalisation (Harvey, 2012). However, the majority of people continue to live 'local lives' in particular places and neighbourhoods with different local geographies and role/s in social cohesion. In these local lives the neighbourhood often functions as a set of resources (Witten et al., 2003), which can be material (for example buildings, public spaces), institutional (for example schools or other welfare services), relational (for example support networks among people in the neighbourhood, 'neighbouring') or immaterial (aspirations, dreams, images, reputation and so on).

The current multi-faceted crisis and the austerity policies implemented as 'remedies' have already severely impacted most of the above resources, for example through cuts in wages and services and reduced maintenance of infrastructures and public spaces. Urban neighbourhoods emerge as an important, though not unique, scale in the process of coping with the crisis, a scale at which alternative bottom-up (or bottom-linked) everyday routines and practices develop. These practices range from mutual assistance to complex solidarity networks and acquire a renewed importance in the present situation, as even minimal acts of reciprocity and mutual support may be crucial for survival and may mobilise processes of inclusion or at least allow residents to benefit from a certain conviviality. They may also lead to important connections and attachments to place, particularly for those residents who spend most of their time at the local setting. It must be emphasised, however, that people's time geographies differ significantly, as do practices and processes for social inclusion. ${ }^{2}$

Solidarity initiatives and alternative ways to access services that have been curtailed or completely cut, including housing, share many of the 
features that are analysed as social innovation and conceptualised as part of social mobilisation intended to counteract the exclusion of entire social groups and the dismantling of the welfare state while attempting, at the same time, to forge social ties in a fragmented society. In many ways, the actors involved in these practices go beyond common principles of the universalistic welfare state and become directly involved in the production and mutual practices of assistance and services. In these solidarity initiatives, different forms of governance are produced, including complex mixes of formal/institutional involvement and intervention (for example in the domain of social services) with informal 'ways of doing'. 3 Such mixes help to put in context the importance of formal rights along with the significance of informal practices, both of which are closely linked and mobilise mechanisms of inclusion and feelings of belonging (Kalandides and Vaiou, 2012). Such processes resonate with a conception of neighbourhood as changing, open and contingent rather than bounded, permanent and static, as a place constituted by a particular set of social relations which interact in a given location, by movement and contacts which may be local but also extend beyond it (Massey, 2005).

\section{SOCIAL INNOVATION: HOUSING AND NEIGHBOURHOOD RESPONSES IN TIMES OF AUSTERITY}

\section{Different Shades of Social Innovation}

Ongoing restructurings of European welfare states, in both their 'strong' Scandinavian and their 'weaker' Southern European versions (see Martinelli, Chapter 1, in this volume), have resulted in unmet needs and difficulties of access to housing and neighbourhood services, particularly for the most vulnerable groups in European societies. At the same time, these difficulties have contributed to the emergence of alternative projects and bottom-up initiatives, studied as social innovation in a wide-ranging body of literature which has been developing since the early 2000s in many fields and disciplines (for reviews see Klein et al., 2014; Moulaert et al., 2013; Mulgan et al., 2007).

In this section a reading of a number of such initiatives is provided, through the lens of social innovation and particularly its strand concerned with local development. The cases illustrate the main argument of the present chapter, which stresses the societal responses at neighbourhood and city level to the negative effects of the (re-)commodification of housing and the impacts of the financial and economic crisis, which 
threaten the overall welfare of neighbourhoods. Some are examples of direct responses to the retrenchment of the State as part of the reformation of housing systems and austerity policies, and emerge as micro solutions to immediate needs of vulnerable sectors of the population (the cases of Calabria, Athens, Sweden, Slovakia and Milan). In other instances, they occur as bottom-up movements that contest the effects of privatisation and have a more political orientation in that they pose a challenge to the institutional level (the cases of Barcelona and Vienna). The main differences between the two types of initiatives are the visibility of the actors' innovative actions, their open confrontation with private and public institutions in the public sphere and the level of institutionalisation of the innovative practices.

Our analysis is informed by a specific reading of the concept of social innovation that emphasises three constitutive elements. First, practices are considered socially innovative if they contribute to satisfying basic human needs that remain unmet by the State or the market. Second, satisfaction of these needs occurs thanks to a change taking place in the governance system that steers and regulates the allocation of goods and services meant to satisfy them; third, the change in the governance system is the result of a process of individual and collective empowerment. Therefore, social innovation closely relates to the socio-spatial context and has to be assessed with reference to local social, economic, cultural and political structures.

Our analysis of specific innovative practices concerning housing and neighbourhood services starts with their identification in terms of the specific need they address and the social exclusion dynamics that can be said to produce that need; it then identifies the actors that are mobilised at different institutional levels and examines the extent of re-distribution of material and immaterial resources. We then assess social innovation along two dimensions: the degree of institutionalisation of innovative practices and the value orientation. The process of institutionalisation concerns the mutual recognition between the State and civil society associations and organisations achieving a certain degree of stability; this process induces innovation in public policies and influences public discourse relating to agenda-setting and to the finding of solutions. We analyse innovative practices and policies together, because what is interesting is, above all, the process of bringing new or alternative values into the public sphere, independently of the level of (formal) institutionalisation. The value orientation, which is the foundation of the actors' motivation, the 'fuel', so to speak, of social innovation (Vicari Haddock and Tornaghi, 2013), concerns the degree to which the action is oriented toward progressive social change, that is social justice, equality, democracy and empowerment. This value orientation signals the presence of alternative models vis-à-vis those 
that privilege the market economy, representative democracy, traditional cultural values, etc.; instead, socially innovative initiatives are centred on non-profit economic activities, the empowerment of people and their direct involvement in decision-making processes, the pursuit of social justice, equal opportunities and gender equality and the appreciation of diversity.

\section{Examples of Social Innovation Practices}

With regard to practices and services responding to housing needs, we see a somewhat renewed commitment and/or mobilisation for housing rights along with attention focused on excluded populations in housing provision, such as homeless and Roma groups. Our first illustration is the cross-national programme of Housing First, a programme for homeless people that started in the USA, in which some elements of co-production, self-determination and empowerment are present (Tsemberis et al., 2004). Introduced with different levels of institutionalisation in several countries, this policy promotes social inclusion by giving priority to housing access. This policy involves a re-organisation of welfare provision where there is a mutual accommodation between a public responsibility still strongly felt and the opening of the field of social services to not-for-profit providers. Housing First is thus understood as a way of quick re-integration into a completely self-determined but assisted life for a broad group of homeless people.

In Sweden, for example, Housing First has been implemented in a number of municipalities as a possible solution to combat growing homelessness, in the context of the dismantling of the Swedish housing system, the devolution of responsibility to municipalities and the activation of NGOs in the field (CAP Knutagård, 2014). The Housing First project is a research-driven initiative and a response to demand for access to housing for those who cannot afford to rent a place to live temporarily or permanently and do not qualify for institutionalised housing services. As Knutagård and Kristiansen (2013, p. 102) argue, Housing First in Sweden challenges institutional practice within the 'staircase' model, which is a multistage approach where individuals move through a number of steps and where independent living is only for those who finally qualify. Thus, introducing Housing First has involved a breakthrough in the governance of housing for the homeless and people in need of decent and affordable housing. From a governance perspective, the Swedish version of Housing First involves coordination with other social services, although Housing First services do not require compliance with treatment. This case illustrates two processes characteristic of the transformation of welfare 
systems, with the help of innovative approaches: changing institutional practice in response to unmet needs and the involvement of diverse actors.

Earlier in the chapter we looked closely at the contextual dimension of social innovation. This aspect becomes clearer when looking closely at how specific innovative projects cause changes in governance relations between national and local welfare institutions and civil society groups. A pilot project of Housing First in Vienna shows a strong role of both the municipal government as financing institution and regulator and of Neunerhaus, an organisation born out of a civic movement. The latter runs several emergency accommodations and houses for temporary living and provides social assistance and medical services for homeless people. The co-operation between the local institutions and the civic organisations has enabled a new governance principle to emerge concerning the participation and self-determination of homeless people. It has also promoted debates about housing accessibility criteria for targeted groups as well as a proposal to develop a more coordinated approach among providers of social housing for homeless people. In a national context in which social dwellings represent 23 per cent of the total housing stock, the Vienna case speaks also to the limits of a policy narrowed down to the small target group of the currently homeless while failing to address the structural conditions that increase the risks of becoming homeless. However, this social innovation showed multiple strengths: the empowerment of the target group, the growing public awareness of the structural links between homelessness and dynamics of the housing market and the changes in governance relations towards a more open and deliberative form (Weinzierl et al., 2016).

A contrasting case was found in an Eastern European context. The privatisation of housing has been particularly striking in post-communist countries. In these societies housing as a social right and welfare has been strongly challenged by market forces, resulting in the marginalisation or exclusion of lower-income groups, many of whose members often belong to cultural or ethnic minorities. For example, the proportion of social dwellings in Slovakia has been reduced to less than 10 per cent of the total housing stock. In these circumstances, the emergence of innovative strategies becomes an illustration of what a more generalised policy of social innovation could entail. In Slovakia where the Roma people have been hardest hit by the post-1989 changes and the dismantling of social housing, the project Building Hope, which combined self-construction with a microloan programme, offered the Roma better living conditions by integrating housing issues with other policies related to social empowerment. In order to implement the project, a broad coalition of public and 
private sector actors was established, which was able to change the perception of the Roma in the community and influence local policy-making processes (Szüdi and Kovácová, 2016). This case is particularly interesting because it illustrates the relevance of political empowerment. As the Roma community got a local mayor to represent them in the small Eastern Slovak municipality of Rankovce he was able to gather local, national and international financial resources and support in order to implement an inclusionary housing programme for the Roma minority. We argue, then, that the social innovation content here is strong, as the project empowers people with new, marketable skills while forging new partnerships in the governance system.

In Southern European countries, where austerity programmes have been implemented forcefully, a variety of responses have appeared as alternative solutions to the exclusionary potential of housing developments. In Italy, where social dwellings have become only 4 per cent of total housing stock, the recent economic crisis has dramatically decreased house affordability, as housing prices for purchase and renting have increased by 100 per cent and 70 per cent respectively in the decade prior to the financial crisis, while income levels have stagnated since 2008. The economic crisis and the growth of unemployment have resulted in the worsening of the situation for foreign immigrants. In this context, the associated and assisted self-building projects Paderno Dugnano (2005-12) and Casalmaggiore (2007-11) in which local residents were directly involved in the construction of the houses with their labour and organisational capacity, lowering housing production costs, implicated both user empowerment and the production of social capital in the process. Self-building projects have also been implemented, with the specific aim of fostering integration between migrants and the local population. The most successful cases are located in the metropolitan area of Milan, where volunteers and/or families built their own houses in their free time/outside working hours. Semprebon and Vicari Haddock (2016) show also the governance constraints in the implementation of otherwise innovative solutions, in line with the current trend of giving civil society and citizens in general more responsibility in the provision of 'active community welfare' (Annette and Mayo, 2010). These and other Italian cases exemplify mixed governance between public institutions (the Lombardy Region, the Province of Milan, municipalities) and local actors. Although the dialogue between civil society actors and the public administration appears fraught with difficulty and thus unable to ensure the sustainability of programmes, the Milan cases show possible choices in a more flexible governance context that can serve as a model for other countries. In general, it can be argued that the social innovation content is quite strong in all cases of self-building projects as they empower people 
with new, marketable skills and forge new partnerships in the governance system.

In Calabria, in the South of Italy, the emergency landing of asylum seekers starting in the late 1990s triggered renewed attention to unused housing stock as a resource to be exploited for socially innovative forms of responses to housing needs and local development. Among the most interesting instances are the projects by the municipalities of the so-called 'Dorsale dell'ospitalità' where building-rehabilitation projects to provide accommodation for refugees were integrated into a broader strategy of urban regeneration and re-population of old boroughs, which included the re-modelling of public spaces, the revitalisation of old trades and crafts, the recovery and re-launching of cultural activities, in the context of an alternative tourism model, called 'solidarity tourism'. The hosting of refugees was taken as an opportunity to achieve the more ambitious aim of local redevelopment (CAP Sarlo and Martinelli, 2016).

In the case of Athens, the practices of survival, solidarity and resistance in the city seem ultimately to have reshaped the public sphere during the crisis years. The fields of action range from educational facilities to communal cooking, free clinics and neighbourhood assemblies, exemplifying what community needs and community support involve. Solidarity networks after 2011, such as Myrmigi, are examples of organised citizens operating as welfare providers with material resources collected from other citizens. Another example is the Hellinikon Social Medical Ward and Social Pharmacy (MKIE) network of doctors who provide healthcare on a voluntary basis. The actors involved in these practices are redefining the concept of the public sphere, going beyond political participation to include welfare socialisation. From a governance perspective, these cases show challenging situations for institutional policy implementation and for developing instruments with the input of bottom-up collective action (Vaiou and Kalandides, 2016).

A final example can be taken from specific instances of mobilisation and civic groups' activation. These instances are part of the development and the increasing articulation of movements for emancipation and democratisation opposing traditional and novel forms of oppression and domination (Fraser, 2011). The values of these movements nourish contemporary mobilisation in its multiple forms as well as civil society organisations motivated to work for social change with a progressive and inclusive orientation. With reference to housing issues, there is the example of the Stop evictions campaign and the $\mathrm{PAH}$ - Plataforma d'afectats per la hipoteca (Platform of mortgage victims) movement in Barcelona in 2009, following the bursting of the housing bubble in Barcelona and other big cities in Spain which left large numbers of households in precarious 
housing conditions. The socially innovative initiative transformed itself into a social movement and demonstrated organisational capacities that produced a creative bottom-up governance process in sequential stages. After achieving support at the neighbourhood level, it managed to scale up to city, regional, national and European public spheres. The movement reached European institutions, which forced the Spanish government to revise legislation and take policy action (De Weerdt and García, 2016). Partly in response to the PAH's effective campaigns, financial institutions and public institutions modified some governance regulations concerning mortgage payment conditions. The combination of a grassroots protest movement with bottom-linked dialogue and co-operation with local and regional public administrations has proved an effective way to deal with the housing needs of the affected population. Positive outcomes have been the relocation of hundreds of families in social dwellings and new investment in social housing by municipalities in a country where social dwellings accounts for less than 2 per cent of total housing stock. The impact of this case has reached beyond those described previously because of the consequent changes in governance. Actors involved in social innovation carried their mobilisation from the local to the national public sphere and the organisational strategy of the social movement used political confrontation as a resource. This strategy has been instrumental in bringing about changes in governance and in legislative outcomes.

\section{CONCLUSIONS}

In this chapter we have argued that the fundamental needs relating to housing and neighbourhood life have been increasingly unanswered in the last two decades. Particularly since the beginning of the 2008 financial crisis, the imposition of fiscal austerity has reduced the provision of social housing and social benefits to the detriment of the most vulnerable social groups, old and new. At the same time, national responses to increasing social needs have been slow or deficient. Instead, responses to the needs for housing and community services have appeared at the neighbourhood and municipal levels (Moulaert et al., 2013). This means that local governments, in order to cope with housing and neighbourhood needs, have to continue to develop responses to avoid further social exclusion while at the same time negotiating financial arrangements with regional and national governments. Moreover, local governments are increasingly relying on the contribution of other actors such as NGOs, for-profit associations or active citizens organised for specific social needs. As a result, in addition to negotiations developed vertically, new horizontal governance 
configurations develop among diverse actors attending to housing and neighbourhood service needs. This is especially the case in Southern European countries where social solidarity from below has emerged at the neighbourhood level to complement diminished state investment.

We see in the cases examined in the COST Action that innovative practices in housing and neighbourhood that are able to restore a sense of belonging in cities have been implemented through co-operation between civil society, public institutions and market actors in order to achieve the objectives of social and housing inclusion. Should policy instruments be redesigned according to the emerging scenarios? What can be learned from these cases in terms of policy?

All innovative initiatives and projects examined in the COST Action show that it is the interaction of citizens working with formal and informal organisations, in civil society and in the public sector, which is the most important driver of social innovation. Not all such initiatives, however, are conducive to the development of cohesive and inclusive territorial systems: crucial to the full development of social innovation along all the dimensions outlined in this chapter is the ability of the organisations involved (civil society, resident groups and administrations) themselves to be innovative and creative, to have the flexibility and openness to engage fully with residents and to look beyond existing institutional arrangements to find opportunities for collaboration and co-production. It is up to these organisations to provide both the opportunity for residents to exercise a high degree of control over the future of their housing and neighbourhood and the supportive framework to help them to achieve it. Important as these bottom-up actions may be as responses to social needs, to achieve lasting results they need institutional support. It is arguable from the evidence of the cases presented in this chapter and from other cases (see Moulaert et al., 2013) that a renewed welfare-state framework may provide the best environment for the active participation of the most marginal; short of this there are only processes of 'expulsion' from society (Sassen, 2014). In other words, we maintain that bottom-up action works best when seen as a complement, rather than an alternative, to the welfare state.

Perhaps the first question that needs to be addressed by a renewed welfare state is a conceptual one. There is a case for changing the emphasis in housing debates from a market concept - affordability - to the social concept of accessibility. By calling for housing accessibility, social movements are putting forward (again) the notion of housing as a social right to be guaranteed for every human being (Sendi, 2011). We have seen that the trend towards home ownership and market-based rents implies that access and affordability of housing become difficult for many households. There is an implicit danger of 'blaming the victim' for not being able to afford 
what the market provides. Even if governments provide programmes to help pay for accommodation under specific circumstances, the notion of help falls short of the notion of a social right.

The second question refers to the limited power of local administrations. The crisis that began in 2008 has shown that in many cities local authorities have increasing difficulties in meeting housing and collective needs. In some countries, local administrations have limited financial capacity to address housing problems, partly because local policy in relation to housing continues to play only a marginal role. As a result, local housing policies are unable to respond to growing social problems, made worse by added responsibilities that are shifted to the local community and the neighbourhoods (Zwiers et al., 2016). The crisis has shown that the central state continues to be the key player regulating the housing market. Governments in countries that were strongly affected by the financial crisis have resorted to stricter mortgage regulations and capital requirements to avoid high-risk loans to households; this may exclude low-income households from buying their own house (Whitehead et al., 2014). This exclusion makes some analysts recommend focusing on social innovation in seeking solutions (Costa et al., 2014).

The third question that requires attention is the neighbourhood as a particular form of non-bounded spatial scale, a place, in the sense of Doreen Massey's formulation, constituted by far-reaching relations, as well as by everyday practices (1994). The neighbourhood is a privileged place of everyday life and an arena for claims to the city, including claims to do with things as 'mundane' as the provision of social services, whose curtailing destabilises processes of social inclusion. Indeed, urban neighbourhoods in many European cities become the medium in struggles for inclusion and belonging (for a discussion, see Kalandides and Vaiou, 2012). From such a perspective, even if social innovation practices originate in or are identified with a particular place/neighbourhood, the links with different spatial scales and levels of governance constitute an essential component of an analytical and policy framework.

\section{NOTES}

1. It has to be kept in mind that the COST Action IS1102 SO.S. COHESION was not a research project with a structured theoretical and methodological framework. Cases are presented in this chapter as examples or illustrations of the trends discussed and of specific, collective ways of meeting social needs.

2. As examples from crisis-ridden neighbourhoods indicate, it is not uncommon to experience conflicts and aggression on the basis of different forms of 'otherness' (e.g. ethnicity, religion, gender, sexuality). The current refugee crisis in the EU is a bitter example. 
3. The PAH movement in Barcelona and in Spain more generally exemplifies, among other things, this complexity (De Weerdt and García, 2016).

\section{REFERENCES}

Annette, J. and M. Mayo (2010), Taking Part: Active Learning for Active Citizenship, and Beyond, Leicester: NIACE - The National Institute of Adult Continuing Education.

Bengtsson, B. (2001), 'Housing as a social right: implications for welfare state theory', Scandinavian Political Studies, 24 (4), 255-75.

Cassiers, T. and C. Kesteloot (2012), 'Socio-spatial inequalities and social cohesion in European cities', Urban Studies, 49 (9), 1909-24.

CECODHAS - European Social Housing Observatory (2012), 'Impact of the crisis and austerity measures on the social housing sector', CECODHAS Housing Europe's Observatory Research Briefing, 5 (2), accessed at www.housingeurope. eu/resource-127/impact-of-the-crisis-and-austerity.

Cheshire, P. and S. Sheppard (2004), 'Introduction to feature: the price of access to better neighbourhoods', The Economic Journal, 114 (November), F391-F396.

Clapham, D. (2006), 'Housing policy and the discourse of globalization', International Journal of Housing Policy, 6 (1), 55-76.

Costa, G., G. Bezovan, P. Palvarini and T. Brandsen (2014), 'Urban housing systems in times of crisis', in C. Ranci, T. Brandsen and S. Sabatinelli (eds), Social Vulnerability in European Cities: The Role of Local Welfare in Times of Crisis, London: Palgrave Macmillan, pp.161-86.

De Weerdt, J. and M. García (2016), 'Housing crisis: the Platform of Mortgage Victims (PAH) movement in Barcelona and innovations in governance', Journal of Housing and the Built Environment, 31 (3), 471-93.

Doherty, J. (2004), 'European housing policies: bringing the state back in?', European Journal of Housing Policy, 4 (3), 253-60.

Doling, J. and M. Elsinga (2012), 'Housing as income in old age', International Journal of Housing Policy, 12 (1), 13-26.

Edgar, W.M., J.M. Doherty and H. Meert (2002), Access to Housing: Homelessness and Vulnerability in Europe, Bristol: Policy Press.

Fraser, N. (2011), 'Marketization, social protection, emancipation: towards a neoPolanyan conception of the capitalist crisis', in C. Calhoun and G. Derluguian (eds), Business as Usual: The Roots of the Global Financial Meltdown, New York: New York University Press, pp. 138-59.

García, M. and S. Vicari Haddock (2016), 'Special issue: housing and community needs and social innovation responses in times of crisis', Journal of Housing and the Built Environment, 31 (3), 393-407.

Harloe, M. (1995), The People's Home? Social Rented Housing in Europe and America, Oxford: Blackwell.

Harvey, D. (2012), Rebel Cities: From the Right to the City to the Urban Revolution, London: Verso.

Holmqvist, E. and L. Magnusson Turner (2014), 'Swedish welfare state and housing markets: under economic and political pressure', Journal of Housing and the Built Environment, 29 (2), 237-54. 
Kadi, J. and R. Ronald (2014), 'Market-based housing reforms and the "right to the city": the variegated experiences of New York, Amsterdam and Tokyo', International Journal of Housing Policy, 14 (3), 268-92.

Kalandides, A. and D. Vaiou (2012), "Ethnic" neighbourhoods? Practices of belonging and claims to the city', European Urban and Regional Studies, 19 (3), 254-66.

Klein, J.L., J.L. Laville and F. Moulaert (2014), L' Innovation Sociale, Paris: Editions Erès.

Knutagård, M. (2014), 'The moral geography of homelessness', unpublished paper presented at the COST Action IS1102 Workshop, University of Tampere, Tampere, 2-6 June.

Knutagård, M. and A. Kristiansen (2013), 'Not by the book: the emergence and translation of Housing First in Sweden', European Journal of Homelessness, 7 (1), 93-115.

Lefebvre, H. (1968), Le Droit à la Ville, Paris: Anthropos.

Maloutas, T. and M.P. Malouta (2004), 'The glass menagerie of urban governance and social cohesion: concepts and stakes/concepts as stakes', International Journal of Urban and Regional Research, 28 (2), 449-65.

Malpass, P. (2008), 'Housing and the new welfare state: wobbly pillar or cornerstone?', Housing Studies, 23 (1), 1-19.

Massey, D. (1994), Space, Place and Gender, Oxford: Polity.

Massey, D. (2005), For Space, London: Sage.

Moulaert, F. (2009), 'Social innovation: institutionally embedded, territorially (re)produced', in D. MacCallum, F. Moulaert, J. Hillier and S. Vicari Haddock (eds) Social Innovation and Territorial Development, Abingdon: Ashgate, pp. 11-24.

Moulaert, F., D. MacCallum, A. Mehmood and A. Hamdouch (eds) (2013), The International Handbook of Social Innovation. Collective Action, Social Learning and Transdisciplinary Research, Cheltenham, UK and Northampton, MA, USA: Edward Elgar Publishing.

Mulgan, G., S. Tucker, A. Rushanara and B. Sanders (2007), Social Innovation: What it is, Why it Matters and How it Can be Accelerated, Working Paper, Skoll Centre for Social Entrepreneurship, Saïd Business School, Oxford: The Basingstoke Press, accessed at www.sbs.ox.ac.uk/sites/default/files/Skoll_Centre/ Docs $/$ Social $\% 20$ Innovation $\% 20-\% 20$ What $\% 20$ it $\% 20$ is, $\% 20$ why $\% 20$ it $\% 20$ matters $\% 20 \% 26 \% 20$ how $\% 20$ it $\% 20$ can $\% 20$ be $\% 20$ accelerated.pdf.

Norris, M. and N. Winston (2012), 'Home-ownership, housing regimes and income inequalities in Western Europe', International Journal of Social Welfare, 21 (2), $127-38$.

Rodriguez, A. (2009), 'Social innovation for neighbourhood revitalization: a case of empowered participation and integrative dynamics in Spain', in D. MacCallum, F. Moulaert, J. Hillier and S. Vicari Haddock (eds), Social Innovation and Territorial Development, Abingdon: Ashgate, pp. 81-100.

Rolnik, R. (2013), 'Late neoliberalism: the financialization of homeownership and housing rights', International Journal of Urban and Regional Research, 37 (3), 1058-66.

Rolnik, R. (2014), 'Afterword: place, inhabitance and citizenship: the right to housing and the right to the city in the contemporary urban world', International Journal of Housing Policy, 14 (3), 293-300.

Ronald, R. (2012), 'Family property wealth and the new welfare state', Houwel 
Working Paper Series, Working Paper no. 1, Centre for Urban Studies, University of Amsterdam.

Sarlo, A. and F. Martinelli (2016), 'Housing and the social inclusion of immigrants in Calabria. The case of Riace and the "dorsal of hospitality", COST Action IS1102 Working Papers, no. 13, accessed at http://www.cost-is1102-cohesion. unirc.it/docs/working-papers/wg2.italy-calabria-housing-and-social-inclusion-im migrants-sarlo-and-martinelli.pdf.

Sassen, S. (2014), Expulsions: Brutality and Complexity in the Global Economy, Cambridge: Harvard University Press/Belknap.

Semprebon, M. and S. Vicari Haddock (2016), 'Innovative housing practices involving immigrants: the case of self-building in Italy', Journal of Housing and the Built Environment, 31 (3), 439-55.

Sendi, R. (2011), 'Housing accessibility versus housing affordability: introducing universal housing care', paper presented at the Enhr Conference, Toulouse.

Slater, T. (2009), 'Missing Marcuse. On gentrification and displacement', City, 13 (2-3), 293-311.

Szüdi, G and J. Kovácová (2016), "Building hope: from a shack to 3E house" innovative housing approach in the provision of affordable housing for Roma in Slovakia', Journal of Housing and the Built Environment, 31 (3), 423-38.

Tsemberis, S., L. Gulcur and M. Nakae (2004), 'Housing First, consumer choice and harm reduction for homeless individuals with a dual diagnosis, American Journal of Public Health, no. 94, 651-6.

Vaiou, D. and A. Kalandides (2016), 'Practices of collective action and solidarity: reconfigurations of public space in crisis-ridden Athens - Greece', Journal of Housing and the Built Environment, 31 (3), 457-70.

Vicari Haddock, S. and C. Tornaghi (2013), 'A transversal reading of social innovation in European cities', in F. Moulaert, D. MacCallum, A. Mehmood and A. Hamdouch (eds), The International Handbook on Social Innovation. Collective Action, Social Learning and Transdisciplinary Research, Cheltenham, UK and Northampton, MA, USA: Edward Elgar Publishing, pp. 264-74.

Weinzierl, C., F. Wukovitsch and A. Novy (2016), 'Housing first in Vienna: a socially innovative initiative to foster social cohesion', Journal of Housing and the Built Environment, 31 (3), 409-22.

Whitehead, C., K. Scanlon and J. Lunde (2014), The Impact of the Financial Crisis in European Housing Systems: A Review, Stockholm: Swedish Institute for European Policy Studies.

Witten, K., T. McCreanor and R. Kearns (2003), 'The place of neighbourhood in social cohesion: insights from Massey, West Auckland', Urban Policy and Research, 21 (4), 321-38.

Zwiers, M., G. Bolt, M. van Ham and R. van Kempen (2016), 'The global financial crisis and neighbourhood decline', Urban Geography, 37 (5), 664-84. 